ISSN: 2302-8556

E-Jurnal Akuntansi Universitas Udayana

Vol.25.3.Desember (2018): 1773 - 1798

DOI: https://doi.org/10.24843/EJA.2018.v25.i03.p06

\title{
Pengaruh Kualitas Pelayanan, Sanksi Pajak, Biaya Kepatuhan Pajak dan E-Filling Pada Kepatuhan WPOP Non PNS
}

\author{
Ida Bagus Komang Wiryadana ${ }^{1}$ \\ Ni Ketut Lely Aryani Merkusiwati²
}

${ }^{1}$ Fakultas Ekonomi dan Bisnis Universitas Udayana (Unud), Bali, Indonesia
email: wiryadana18@gmail.com /Telp: +62 81339742007
${ }^{2}$ Fakultas Ekonomi dan Bisnis Universitas Udayana (Unud), Bali, Indonesia

\begin{abstract}
ABSTRAK
Kepatuhan wajib pajak adalah perilaku dari seorang wajib pajak dalam melakukan semua kewajiban perpajakan dan menggunakan hak perpajakannya dengan tetap berpatokan kepada peraturan perundang-undangan perpajakan. Isu mengenai kepatuhan perpajakan yang terjadi beberapa tahun terakhir ini adalah ketidakpatuhan perpajakan. Ketidakpatuhan ini akan menimbulkan penghindaran dan penggelapan pajak yang menyebabkan berkurangnya penerimaan pajak ke kas negara. Tujuan penelitian ini adalah untuk mengetahui pengaruh kualitas pelayanan, sanksi pajak, biaya kepatuhan pajak, dan penerapan e-filling pada kepatuhan pelaporan Wajib Pajak Orang Pribadi (WPOP).Penelitian ini dilakukan di KPP Pratama Denpasar Timur. sampel yang diambil sebanyak 100 WPOP non PNS, dengan metode nonprobability sampling dengan teknik purposive sampling. Pengumpulan data dilakukan melalui wawancara, observasi dan kuesioner. Teknik analisis yang digunakan dalam penelitian ini adalah regresi linier berganda.Berdasarkan hasil analisis diperoleh kualitas pelayanan, sanksi perpajakan, dan penerapan $e$-filling berpengaruh positif pada kepatuhan WPOP, sedangkan biaya kepatuhan pajak berpengaruh negatif pada kepatuhan WPOP.
\end{abstract}

Kata kunci: kualitas pelayanan, sanksi pajak, biaya kepatuhan pajak, dan $e$-filling

\begin{abstract}
Tax compliance is the behavior of a taxpayer in performing all tax obligations and use his taxation rights by sticking to the regulations of taxation legislation. The issue of tax compliance that has occurred in recent years is non-tax compliance. This non-compliance will result in tax evasion and embezzlement causing reduced tax revenue to the state coffers. The purpose of this study is to determine the effect of service quality, tax sanctions, tax compliance, and e-filling on compliance reporting Individual Taxpayer (WPOP). The number of samples is 100 WPOP non PNS, with nonprobability sampling method with purposive sampling technique. Data collection was done through interview, observation and questionnaire. The analytical technique used in this study is multiple linear regression. Based on the analysis result obtained service quality, taxation sanction, and application of e-filling have a positive effect on WPOP compliance, while tax compliance cost have negative effect on WPOP compliance.

Keywords : service quality, tax sanction, compliance cost, and e-filling
\end{abstract}

\section{PENDAHULUAN}

Pembangunan nasional adalah kegiatan yang berlangsung secara terus menerus dan berkesinambungan yang bertujuan untuk meningkatkan kesejahteraan rakyat (Everest-Philips, 2009). Pemerintah membutuhkan dana yang relatif besar untuk 
Ida Bagus komang Wiryadana dan Ni Ketut Lely Aryani Merkusiawati. Pengaruh...

menyelenggarakan pemerintahan umum dan melaksanakan pembangunan (Ibtida, 2010). Anggaran Pendapatan dan Belanja Negara (APBN) selalu ditingkatkan oleh pemerintah untuk membiayai pembangunan yang ingin diwujudkan. Pengeluaran untuk pembangunan nasional tersebut dapat dibiayai dengan dana yang berasal dari dalam negeri (sumber internal) maupun melalui pinjaman luar negeri (sumber eksternal). Salah satu sumber pembiayaan pembangunan yang berasal dari dalam negeri yang potensial untuk terus digali dan ditingkatkan adalah penerimaan di sektor perpajakan. Berdasarkan data dari Kementrian Keuangan Republik Indonesia, jumlah pendapatan negara terbesar pada tahun 2017 berasal dari sektor pajak. Hal tersebut dapat dilihat pada Tabel 1 tentang penerimaan pendapatan negara pada tahun 2017 sebagai berikut.

\section{Tabel 1.}

Pendapatan Negara Tahun 2017

\begin{tabular}{ccc}
\hline Sumber Penerimaan Negara & $\begin{array}{c}\text { Jumlah Penerimaan } \\
\text { (Triliun Rupiah) }\end{array}$ & Penerimaan (\%) \\
\hline Pajak & 1.749 & 53,83 \\
PNBP & 1.499 & 46,13 \\
Hibah & 1,4 & 0,04 \\
\hline
\end{tabular}

Sumber: www.kemenkeu.go.id, 2018

Berdasarkan Tabel 1 tersebut dapat dilihat sumber penerimaan pajak yang terbesar, yaitu sebesar 53,83 persen, selanjutnya diikuti oleh sumber penerimaan negara bukan pajak (PNBP) sebesar 46,13 persen serta hibah sebesar 0,04 persen. Hal tersebut membuktikan bahwa kontribusi pajak sangat signifikan dalam pendapatan negara untuk dapat menyelenggarakan pemerintahan umum dan melaksanakan pembangunan. 
Sebagai salah satu unsur penerimaan negara, pajak memiliki peran yang sangat besar dan semakin diandalkan untuk kepentingan pembangunan dan pengeluaran pemerintahan. Besarnya konstribusi penerimaan pajak tersebut sangat memengaruhi jalannya roda pemerintahan dan perekonomian seperti pendanaan pembangunan demi kemakmuran rakyat yang dimulai dari sektor pendidikan, kesehatan, perbankan dan juga sektor industri (Supadmi, 2009).

Langkah pemerintah untuk meningkatkan penerimaan dari sektor perpajakan dimulai dengan melakukan reformasi perpajakan secara menyeluruh pada Tahun 1983, dengan mengganti official assessment system menjadi self assessment system. Dianutnya self assessment system membawa misi dan konsekuensi perubahan sikap (kesadaran) warga masyarakat untuk membayar pajak secara sukarela (Harahap, 2004:43).

Menurut Togler (2005) salah satu masalah yang paling serius bagi para pembuat kebijakan ekonomi adalah mendorong tingkat kepatuhan wajib pajak. Terancamnya upaya pemerintah untuk dapat meningkatkan kesejahteraan dikarenakan tingkat kepatuhan pajak secara tidak langsung dapat memengaruhi ketersediaan pendapatan untuk keperluan belanja negara (Jung, 1999). James dan Alley (2004) menyatakan kepatuhan pajak adalah subjek yang kompleks dengan implikasi yang luas dan yang memengaruhi kepatuhan tersebut ada dua pendekatan yaitu ekonomi dan perilaku. Kepatuhan wajib pajak (tax compliance) dapat diidentifikasi dari kepatuhan wajib pajak dalam mendaftarkan diri, kepatuhan untuk menyetorkan kembali Surat Pemberitahuan (SPT), kepatuhan 
Ida Bagus komang Wiryadana dan Ni Ketut Lely Aryani Merkusiawati. Pengaruh...

dalam penghitungan dan pembayaran pajak terutang, dan kepatuhan dalam pembayaran tunggakan (Chou, 2009) .

Kepatuhan wajib pajak dalam melaksanakan kewajiban di bidang perpajakan akan sangat mendorong peningkatan penerimaan negara dari sektor pajak baik secara langsung maupun tidak langsung. Kepatuhan wajib pajak dipengaruhi oleh beberapa faktor, salah satunya adalah kualitas pelayanan. Zeithaml (2009), pelayanan yang berkualitas adalah pelayanan yang dapat memberikan kepuasan kepada pelanggan dan tetap dalam batas memenuhi standar pelayanan yang dapat dipertanggungjawabkan serta harus dilakukan secara terusmenerus. Nugroho (2005) menyatakan bahwa kepuasan yang diperoleh oleh wajib pajak akan berdampak pada kepatuhan wajib pajak dalam memenuhi kewajiban perpajakannya dengan kata lain kualitas pelayanan yang dirasakan sama dengan kualitas pelayanan yang mereka harapkan dikatakan berkualitas. Kualitas pelayanan juga dinilai sebagai perbandingan antara harapan yang dingiinkan oleh pelanggan dengan penilaian mereka terhadap kinerja aktual dari suatu penyediaan layanan (Cronin, 1992).

Selain kualitas pelayanan, factor yang dapat memengaruhi kepatuhan wajib pajak yaitu sanksi perpajakan. Undang-Undang sudah mengatur ketentuan umum dan tata cara peraturan perpajakan. Sanksi yang dapat diterima kepada WPOP yang melanggar yakni berupa sanksi administrasi seperti bunga, atau pengenaan tarif pajak yang lebih tinggi, denda, serta sanksi pidana berupa kurungan penjara. WP akan memenuhi kewajiban pajak bila memandang bahwa sanksi perpajakan akan lebih banyak merugikannya (Jatmiko, 2006). Ali (2001) 
dalam penelitiannya menyatakan bahwa audit dan sanksi merupakan kebijakan efektif untuk mencegah ketidakpatuhan.

Faktor lain yang dapat memengaruhi kepatuhan wajib pajak adalah Biaya kepatuhan pajak. Biaya kepatuhan pajak merupakan biaya-biaya yang harus dikeluarkan oleh wajib pajak dalam melaksanakan pembayaran perpajakan. Sandford (1995) dalam penelitiannya menjelaskan, biaya kepatuhan pajak (tax compliance cost) dibagi menjadi tiga yakni: 1) biaya uang (direct money cost), 2) biaya waktu (time cost), dan 3) biaya pikiran (psychological cost). Semakin besar biaya yang dikeluarkan oleh WP, maka cenderung akan menyebabkan wajib pajak semakin tidak patuh.

Pesatnya perkembangan penggunaan teknologi informasi dan web, pemerintah juga menggunakan teknologi tersebut dalam memberikan pelayanan dengan tujuan untuk mencapai efisiensi dalam beroperasi guna meningkatkan kualitas pelayanan perpajakan (Parmita Saha et al., 2012). Berdasarkan Keputusan Direktur Jenderal Pajak Nomor Kep-88/PJ/2004 secara resmi telah meluncurkan produk yaitu e-Filing atau Electronic Filling System. e-Filling merupakan sistem penyampaian SPT (Surat Pemberitahuan Tahunan) atau pemberitahuan perpanjangan SPT secara elektronik yang dapat dilakukan melalui sistem online dan real time yang disediakan oleh perusahaan jasa aplikasi yang ditunjuk langsung oleh Dirjen Pajak.

E-filling sebagai salah satu program modernisasi perpajakan merupakan wujud dari e-government yang bertujuan memberikan kemudahan dalam penyampaian SPT tahunan PPh pribadi dengan harapan dapat meningkatkan 
Ida Bagus komang Wiryadana dan Ni Ketut Lely Aryani Merkusiawati. Pengaruh...

kepatuhan wajib pajak orang pribadi (Astuti, 2016). WP yang telah puas terhadap pelayanan ini diharapkan mampu untuk merubah perilakunya dalam memenuhi kewajiban perpajakannya, sehingga berdampak pada peningkatan kepatuhan wajib pajak. Bagi aparat pajak, teknologi e-filling ini mampu memudahkan mereka dalam pengelolaan database karena penyimpanan dokumen-dokumen wajib pajak telah dilakukan secara komputerisasi. Penggunaan e-filling dilakukan bertujuan agar wajib pajak dapat memeroleh kemudahan dalam memenuhi kewajibannya sehingga dapat tercipta administrasi perpajakan yang lebih tertib dan transparan.

Wajib Pajak Orang Pribadi (WPOP) non Pegawai Negeri Sipil (PNS) yang terdaftar di Kantor Pelayanan Pajak (KPP) Pratama Denpasar Timur. Gambaran tingkat kepatuhan dari jumlah Surat Pemberitahuan (SPT) Tahunan Wajib Pajak Orang Pribadi non PNS yang masuk di KPP Pratama Denpasar Timur dapat dilihat pada Tabel 2 berikut ini.

Tabel 2.

Tingkat Kepatuhan Wajib Pajak Orang Pribadi Non PNS di Kantor Pelayanan Pajak Pratama Denpasar Timur Tahun 2013-2017

\begin{tabular}{cccccc}
\hline No & Tahun & $\begin{array}{c}\text { WPOP Non } \\
\text { PNS } \\
\text { yang Terdaftar }\end{array}$ & $\begin{array}{c}\text { WPOP } \\
\text { Non PNS } \\
\text { Efektif (a) }\end{array}$ & $\begin{array}{c}\text { WPOP Non PNS yang } \\
\text { menyampaikan SPT (b) }\end{array}$ & $\begin{array}{c}\text { \% Tingkat } \\
\text { Kepatuhan } \\
\text { (b/a*100) }\end{array}$ \\
\hline 1 & 2013 & 40.324 & 28.554 & 16.368 & 57,32 \\
2 & 2014 & 44.693 & 30.738 & 15.820 & 51,47 \\
3 & 2015 & 49.364 & 34.074 & 16.928 & 49,68 \\
4 & 2016 & 54.042 & 48.413 & 21.175 & 48,41 \\
5 & 2017 & 58.990 & 52.887 & 24.323 & 45,99 \\
\hline
\end{tabular}

Sumber : KPP Pratama Denpasar Timur, 2018

Berdasarkan tabel diatas, dapat dilihat tingkat kepatuhan WPOP non PNS di KPP Pratama Denpasar Timur dari tahun 2013-2017 mengalami penurunan . Pada tahun 2013 persentase kepatuhan sebesar 57,32 persen, di tahun 2014 turun menjadi 51,47 persen, tahun 2015 turun menjadi 49,68 persen, di tahun 2016 juga turun menjadi 48,41 persen, lalu ditahun 2017 besarnya persentase tingkat 
ISSN: 2302-8556

E-Jurnal Akuntansi Universitas Udayana

Vol.25.3.Desember (2018): 1773 - 1798

kepatuhan WPOP non PNS di KPP Pratama Denpasar Timur mengalami penurunan paling tinggi di antara tahun-tahun sebelumnya, yaitu sebesar 45,99 persen.

Berdasarkan Surat Edaran Nomor SE-07/PJ/2017 tentang Strategi Peningkatan Kepatuhan Wajib Pajak dan Penetapan Target Rasio Kepatuhan Wajib Pajak Tahun 2017 disebutkan bahwa target kepatuhan harus mencapai 75 persen. Hal ini menunjukkan bahwa tingkat kepatuhan WPOP di KPP Pratama Denpasar Timur masih rendah sehingga membutuhkan suatu kajian untuk dapat mengetahui penyebab kurangnya kesadaran WPOP dalam membayar kewajiban pajaknya.

Berdasarkan uraian latar belakang di atas, maka rumusan masalah dalam penelitian ini adalah: 1) Bagaimanakah pengaruh kualitas pelayanan pada kepatuhan pelaporan wajib pajak orang pribadi non PNS di KPP Pratama Denpasar Timur?; 2) Bagaimanakah pengaruh sanksi pajak pada kepatuhan pelaporan wajib pajak orang pribadi non PNS di KPP Pratama Denpasar Timur?; 3) Bagaimanakah pengaruh biaya kepatuhan pajak pada kepatuhan pelaporan wajib pajak orang pribadi non PNS di KPP Pratama Denpasar Timur?; 4) Bagaimanakah penerapan sistem e-filling pada kepatuhan pelaporan wajib pajak orang pribadi non PNS di KPP Pratama Denpasar Timur?. Tujuan dalam penelitian ini adalah untuk mengetahui pengaruh kualitas pelayanan, sanksi pajak, biaya kepatuhan pajak dan penerapan e-filling pada kepatuhan pelaporan wajib pajak orang pribadi non Pegawai Negeri Sipil di KPP Pratama Denpasar Timur. 
Ida Bagus komang Wiryadana dan Ni Ketut Lely Aryani Merkusiawati. Pengaruh...

Tujuan penelitian tersebut, peneliti berharap berdasarkan hasil penelitian ini dapat memberikan manfaat secara teoritis maupun praktis. Kegunaan teoritis dalam penelitian ini diharapkan dapat membantu menambah pengetahuan dan memberikan tambahan bukti empiris untuk memperkuat dukungan atas theory of planned behavior (TPB) dan technology acceptance model (TAM) dengan fenomena yang berhubungan mengenai pengaruh kualitas pelayanan, sanksi perpajakan, biaya kepatuhan pajak dan penerapan e-filling pada kepatuhan pelaporan wajib pajak orang pribadi non PNS. Sedangkan kegunaan praktis penelitian ini diharapkan dapat memberikan masukan yang bermanfaat mengenai pengaruh kualitas pelayanan, sanksi pajak, biaya kepatuhan pajak, dan penerapan sistem $e$-filling pada kepatuhan pelaporan wajib pajak orang pribadi non PNS agar menjadi bahan evaluasi atas pengambilan keputusan di masa mendatang oleh pihak pembuat kebijakan perpajakan.

Kajian pustaka dalam penelitian ini adalah Theory of Planned Behavior (TPB) dan Technology Acceptance Model (TAM). Theory of Planned Behavior (TPB) merupakan teori yang menjelaskan bahwa perilaku yang ditimbulkan oleh individu muncul karena adanya niat untuk berperilaku. Teori ini menyatakan bahwa keputusan untuk menampilkan tingkah laku tertentu adalah proses rasional yang diarahkan pada suatu tujuan tertentu dan mengikuti urutan berpikir. faktor sentral dari perilaku individu adalah bahwa perilaku dipengaruhi oleh suatu niat (intention) individu terhadap sebuah perilaku tertentu (Ajzen, 1991).

Technology Acceptance Model (TAM) merupakan suatu model untuk memprediksi dan menjelaskan bagaimana pengguna teknologi menerima dan 
menggunakan teknologi tersebut dalam pekerjaan individual pengguna. Tujuan TAM ini adalah untuk menjelaskan sikap individu terhadap penggunaan suatu teknologi. Sikap individu atau reaksi yang muncul dari penerimaan teknologi tersebut dapat bermacam-macam diantaranya dapat digambarkan dengan intensitas atau tingkat pengguna teknologi tersebut. Model TAM awalnya dikenalkan oleh Davis (1989). Hasil penelitian Davis menunjukkan bahwa faktor yang memengaruhi minat penggunaan sistem informasi dipengaruhi oleh persepsi kebermanfaatan (perceived usefulness) dan persepsi kemudahan penggunaan (perceived ease of use).

Kualitas pelayanan adalah pelayanan yang dapat memberikan kepuasan kepada pelanggan dan tetap dalam batas memenuhi standar pelayanan yang dapat dipertanggungjawabkan serta harus dilakukan secara terus-menerus (Supadmi 2014). sanksi perpajakan merupakan jaminan bahwa ketentuan peraturan perundang - undangan perpajakan (norma perpajakan) akan dituruti / ditaati / dipatuhi, dengan kata lain sanksi perpajakan merupakan alat pencegah (preventif) agar wajib pajak tidak melanggar norma perpajakan (Mardiasmo, 2016). Biaya kepatuhan pajak adalah biaya-biaya yang dikeluarkan oleh wajib pajak dalam rangka melakukan pemenuhan kewajiban pajak. e-filling adalah suatu cara penyampaian SPT baik SPT Masa, SPT Tahunan atau Pemberitahuan Perpanjangan SPT Tahunan oleh orang pribadi atau badan ke Direktorat Jendral Pajak secara online. Secara sistematis, kerangka konseptual dalam penelitian ini dapat dilihat pada Gambar 1 sebagai berikut: 


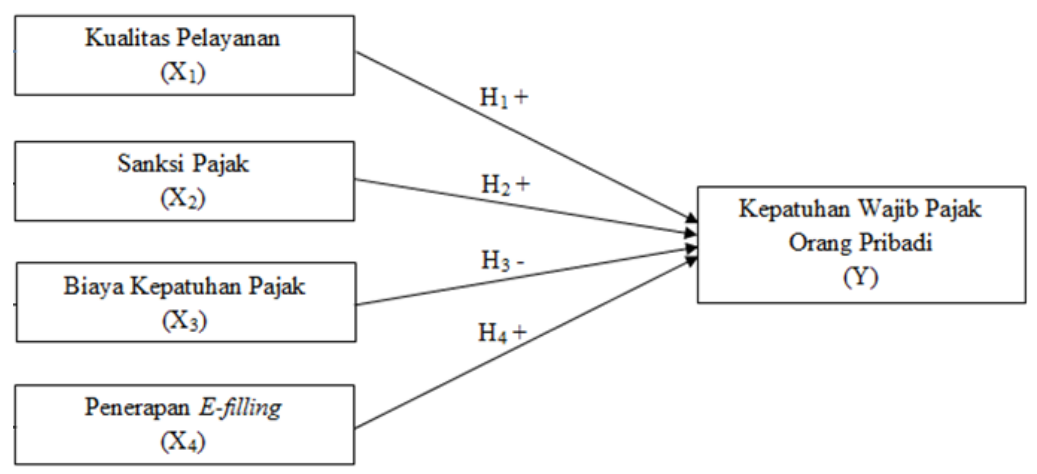

Gambar 1. Kerangka Konseptual

Kualitas Pelayanan pada sektor perpajakan dapat diartikan sebagai pelayanan yang diberikan oleh Direktorat Jendral Pajak kepada wajib pajak untuk membantu wajib pajak memenuhi kewajiban perpajakannya. Menurut Burhanudin (2009), Direktorat Jendral Pajak perlu meningkatkan pelayanan pajak yang baik sesuai dengan ketentuan peraturan perundang-undangan perpajakan yang berlaku, agar menunjang kepatuhan wajib pajak dalam memenuhi kewajiban perpajakannya, dan tercapainya tujuan pemerintah untuk melaksanakan pembangunan dan roda pemerintahan dapat berjalan dengan baik. Penelitian yang dilakukan oleh Farid (2013) dan Putri (2017) menunjukan bahwa kualitas pelayanan pajak berpengaruh positif terhadap kepatuhan wajib pajak. berdasarkan hal tersebut, maka dirumuskan hipotesis sebagai berikut.

$\mathrm{H}_{1}$ : Kualitas pelayanan berpengaruh positif pada kepatuhan pelaporan wajib pajak orang pribadi non pns di kpp pratama denpasar timur.

Sanksi perpajakan merupakan alat pencegah (preventif) agar wajib pajak tidak melanggar norma perpajakan. Terdapat undang-undang yang mengatur ketentuan umum serta tata cara perpajakan, dimana wajib pajak harus melaksanakan peraturan tersebut. Jika peraturan tidak dilaksanakan dengan baik 
atau bahkan dilanggar maka harus ada sanksi yang dikenakan untuk menimbulkan efek jera. Untuk mencegah ketidakpatuhan serta untuk mendorong wajib pajak untuk memenuhi kewajiban perpajakannya maka haruslah diberlakukan sanksi yang tegas dalam rangka untuk memajukan keadilan dan efektivitas sistem pajak (Webley et al., 1991). Sanksi yang tegas akan lebih mendisiplinkan wajib pajak dalam hal ketepatan membayar pajak, ketelitian dalam pengisian dan pelaporan SPT. Muliari dan Setiawan (2011) dalam penelitiannya menyatakan bahwa sanksi perpajakan memiliki pengaruh positif terhadap kepatuhan pelaporan wajib pajak. Arum(2012) dan Yulitasari (2017) juga menyatakan bahwa sanksi perpajakan berpengaruh postif pada kepatuhan pelaporan wajib pajak. Berdasarkan hal tersebut, dapat dirumuskan hipotesis sebagai berikut.

$\mathrm{H}_{2}$ : Sanksi perpajakan berpengaruh positif pada kepatuhan pelaporan wajib pajak orang pribadi non pns di kpp pratama denpasar timur.

Biaya Kepatuhan pajak merupakan biaya-biaya yang ditanggung oleh wajib pajak terkait dengan pemenuhan kewajiban pajak. Hal ini dikarenakan wajib pajak telah berusaha patuh untuk membayar pajak sesuai dengan ketentuan peraturan perundang-undangan perpajakan yang berlaku maka wajib pajak berharap agar dapat mengeluarkan biaya-biaya seminimal mungkin terkait dengan pemenuhan kewajiban pajaknya, meliputi direct money cost maupun time cost dan psychological cost (Sanford, 1989). Namun, apabila jumlah biaya kepatuhan pajak yang dikeluarkan lebih besar daripada ekspektasi wajib pajak, maka akan timbul potensi wajib pajak untuk menjadi tidak patuh dalam melakukan pemenuhan kewajiban pajaknya. Penelitian yang dilakukan oleh Arabella (2013) dan Rara 
Ida Bagus komang Wiryadana dan Ni Ketut Lely Aryani Merkusiawati. Pengaruh...

Susmita (2016) juga mendapatkan hasil penelitian yang sama, yaitu biaya kepatuhan pajak memiliki pengaruh negatif pada kepatuhan wajib pajak. Berdasarkan hal tersebut, maka dirumuskan hipotesis sebagai berikut.

$\mathrm{H}_{3}$ : Biaya kepatuhan pajak berpengaruh negatif pada kepatuhan pelaporan wajib pajak orang pribadi non pns di kpp pratama denpasar timur.

Kemudahan yang dirasakan WP dalam penggunaan e-filling akan membentuk sikap positif dan membuat wajib pajak semakin patuh, karna $e$-filling ini dapat dilakukan dengan cara online dan real time dalam melakukan pelaporan SPT. Menurut Desmayanti (2012) bahwa kesiapan teknologi informasi wajib pajak berpengaruh signifikan positif terhadap intensitas perilaku dalam penggunaan $e$-filling.

Semakin mudah penerapan sistem $e$-filling, maka semakin patuh pula WP tersebut (Punarbhawa dan Lely, 2013). WP yang memandang bahwa e-filing mampu memudahkan dalam melaksanakan kewajiban perpajakan, dapat memberikan kepuasaan bagi wajib pajak tersebut akan penerapan sistem $e$-filling ini. Wulandari (2016) dan juga Santi Krisna (2017) dalam penelitiannya menyatakan bahwa penerapan e-filling berpengaruh positif terhadap kepatuhan wajib pajak. Berdasarkan hal tersebut maka dirumuskan hipotesis sebagai berikut.

$\mathrm{H}_{4}$ : Penerapan sistem e-filling berpengaruh positif terhadap kepatuhan pelaporan wajib pajak orang pribadi non PNS di KPP Pratama Denpasar Timur.

\section{METODE PENELITIAN}

Penelitian ini menggunakan pendekatan kuantitatif dengan tingkat eksplanasi penelitian berbentuk penelitian asosiatif dengan tipe kausalitas adalah penelitian yang menjelaskan pengaruh variabel independen terhadap variabel dependen 
(Sugiyono, 2017:55). Penelitian ini dilakukan untuk mengetahui pengaruh kualitas pelayanan, sanksi pajak, biaya kepatuhan pajak, dan penerapan e-filling pada kepatuhan pelaporan Wajib Pajak Orang Pribadi non PNS di Kantor Pelayanan Pajak Pratama Denpasar Timur. Penelitian ini dilakukan di Kantor Pelayanan Pajak Pratama Denpasar Timur. Objek penelitian dalam penelitian ini adalah kepatuhan pelaporan Wajib Pajak Orang Pribadi non PNS di KPP Pratama Denpasar Timur, khususnya mengenai kualitas pelayanan, sanksi pajak, biaya kepatuhan pajak, dan penerapan e-filling. Populasi penelitian ini yaitu Wajib Pajak Orang Pribadi non PNS yang terdaftar dan yang tergolong wajib pajak efektif di Kantor Pelayanan Pajak Pratama Denpasar Timur, yakni berjumlah 52.887 Wajib Pajak. Non probability sampling merupakan metode pengambilan sampel yang digunakan, yaitu dengan menggunakan teknik purposive sampling. Metode ini digunakan bertujuan untuk menghindari adanya bias dari penelitian dengan memperoleh sampel yang sesuai dengan kriteria yang telah ditentukan. Kriteria-kriteria yang digunakan dalam penelitian ini adalah: 1) Wajib Pajak Orang Pribadi non PNS yang terdaftar dan tergolong wajib pajak efektif di KPP Pratama Denpasar Timur, 2) Wajib Pajak Orang Pribadi non PNS yang berturutturut rutin menyampaikan SPT-nya, 3) Wajib Pajak Orang Pribadi non PNS yang menggunakan sistem e-filling. Metode pengumpulan data yang dilakukan dalam penelitian ini yaitu observasi, wawancara, dan kuesioner.

Teknik analisis data pada penelitian ini adalah Regresi Linier Berganda yang dihitung dengan program SPSS. Pengujian dapat dilakukan apabila model dari penelitian ini telah memenuhi syarat yaitu data harus, tidak mengandung 
Ida Bagus komang Wiryadana dan Ni Ketut Lely Aryani Merkusiawati. Pengaruh...

heteroskedastisitas serta multikolinearitas dan berdistribusi normal (uji asumsi klasik). Pengujian selanjutnya yaitu, uji koefisien determinasi $\left(\mathrm{R}^{2}\right)$, uji kelayakan model (Uji F), setelah itu uji regresi linier berganda, uji hipotesis (Uji t), dan statistik deskriptif. Model regresi penelitian ini dapat ditunjukkan dengan persamaan berikut.

$\hat{Y}=\alpha+\beta_{1} X_{1}+\beta_{2} X_{2}+\beta_{3} X_{3}+\beta_{4} X_{4}+\mathrm{e}$

Keterangan :

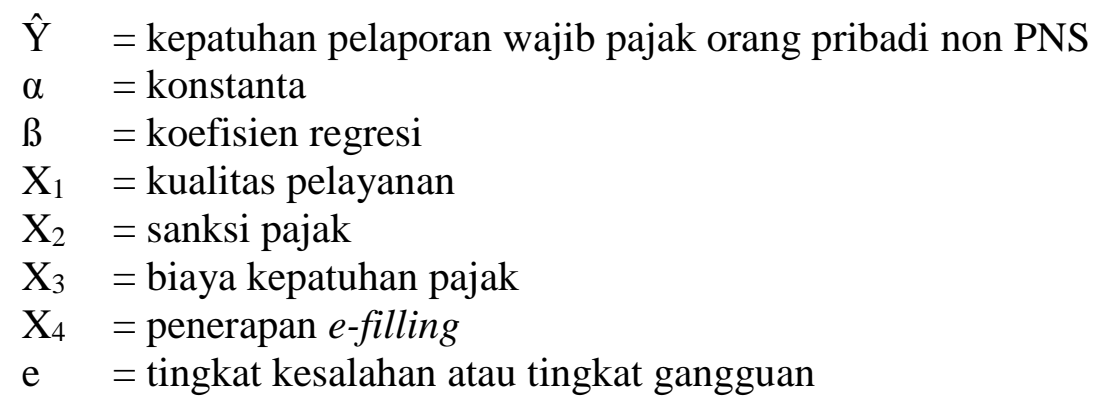

\section{HASIL DAN PEMBAHASAN}

Responden yang digunakan dalam penelitian ini adalah 150 wajib pajak orang pribadi yang menggunakan e-filling dan terdaftar di KPP Pratama Denpasar Timur. Data dalam penelitian ini dikumpulkan melalui penyebaran kuesioner di KPP Pratama Denpasar Timur, kantor swasta dan beberapa usaha kecil di wilayah KPP Pratama Denpasar Timur. Rincian penyebaran kuesioner dapat dilihat pada tabel berikut. 
ISSN: 2302-8556

E-Jurnal Akuntansi Universitas Udayana

Vol.25.3.Desember (2018): 1773 - 1798

Tabel 3.

Rincian Penyebaran Kuesioner

\begin{tabular}{clc}
\hline No & \multicolumn{1}{c}{ Keterangan } & Jumlah \\
\hline 1 & Kuesioner yang disebar & 150 \\
2 & Kuesioner yang tidak kembali & 6 \\
3 & Kuesioner yang tidak lengkap & 7 \\
4 & Kuesioner yang tidak memenuhi kriteria, karena : & 34 \\
& 1) tidak terdaftar sebagai WPOP di KPP Pratama Denpasar Timur; & 3 \\
& 2) tidak menggunakan $e$-filling. & 100 \\
& Jumlah kuesioner yang memenuhi kriteria &
\end{tabular}

Sumber : Data diolah, 2018

Tabel 3 menunjukkan jumlah kuesioner yang disebar sebanyak 150, kuesioner yang tidak kembali sebanyak 6, kuesioner yang tidak lengkap pengisiannya sebanyak 7, dan kuesioner yang tidak memenuhi kriteria sebanyak 37. Sebanyak 34 kuesioner karena tidak terdaftar di KPP Pratama Denpasar Timur dan 3 kuesioner yang tidak memenuhi kriteria karena tidak menggunakan $e$-filling. Jumlah kuesioner yang memenuhi kriteria sebanyak 100 dan kuesioner yang digunakaan dalam penelitian ini adalah 100.

Statistik deskriptif Adalah statistik yang digunakan untuk menganalisa data yang terkumpul dengan cara mendeskripsikan atau menggambarkan data tersebut (Sugiyono, 2014:206). Hasil statistik deskriptif penelitian ini dapat dilihat pada Tabel 4 berikut:

Tabel 4.

Hasil Uji Statistik Deskriptif

\begin{tabular}{lcccccc}
\hline \multicolumn{1}{c}{ Variabel Penelitian } & & N & Minimal & Maximum & Mean & Std. Deviation \\
\hline Kualitas Pelayanan & (X1) & 100 & 7,00 & 27,99 & 21,15 & 5,39 \\
Sanksi Pajak & (X2) & 100 & 5,00 & 19,67 & 14,83 & 3,93 \\
Biaya Kepatuhan Pajak & (X3) & 100 & 6,00 & 22,94 & 11,04 & 5,08 \\
Penerapan -Filling & (X4) & 100 & 6,00 & 22,71 & 17,93 & 4,95 \\
Kepatuhan Pelaporan WPOP (Y) & 100 & 6,00 & 23,03 & 17,38 & 4,87 \\
\hline
\end{tabular}
Sumber : Data diolah, 2018

Tabel 4 menunjukan variabel kualitas pelayanan memiliki nilai minimum 7 dan nilai maksimum 27,99. Nilai rata-rata untuk variabel kualitas pelayanan sebesar 21,15 dengan penyimpangan sebesar 5,39. Hal ini berarti berdasarkan 
Ida Bagus komang Wiryadana dan Ni Ketut Lely Aryani Merkusiawati. Pengaruh...

hasil statistik deskriptif, terjadi perbedaan nilai kualitas pelayanan yang diteliti terhadap nilai rata-ratanya sebesar 5,39.

Variabel sanksi perpajakan memiliki nilai minimum 6 dan nilai maksimum 19,67. Nilai rata-rata untuk variabel sanksi perpajakan sebesar 14,83 dengan penyimpangan sebesar 3,93. Variabel biaya kepatuhan pajak memiliki nilai minimum 6 dan nilai maksimum 22,94. Nilai rata-rata untuk variabel biaya kepatuhan pajak sebesar 11,04 dengan penyimpangan sebesar 5,08.

Variabel penerapan e-filling memiliki nilai maksimum 22,71 dan nilai minimum yaitu 12. Nilai rata-rata untuk variabel penerapan sistem e-filling sebesar 17,93 dengan penyimpangan sebesar 4,95. Variabel kepatuhan pelaporan WPOP memiliki nilai minimum 6 dan nilai maksimum 23,03. Nilai rata-rata untuk variabel kepatuhan WPOP sebesar 17,38 dengan penyimpangan sebesar 4,87 .

Tujuan dilakukannya uji normalitas yaitu untuk menguji apakah dalam residual dari model regresi yang dibuat telah berdistribusi normal. Uji Komogorov-Sminarnov dilakukan untuk menguji uji normalitas. Nilai Asymp. Sig. (2-tailed) yang disajikan pada Tabel 5 yaitu sebesar 0,200, yang dimana lebih besar dari 0,05 maka dapat disimpulkan bahwa seluruh data berdistribusi normal.

Tabel 5.

Hasil UJi Normalitas

\begin{tabular}{cc}
\hline Keterangan & Unstandardized Residual \\
\hline $\mathrm{N}$ & 100 \\
asymp.sig (2-tailed) & 0,200 \\
\hline Sumber $:$ Data diolah, 2018 &
\end{tabular}

Tujuan dilakukannya uji multikolinieritas yaitu untuk menguji apakah dalam model regresi ditemukan adanya korelasi antara variabel independen. Nilai 
ISSN: 2302-8556

E-Jurnal Akuntansi Universitas Udayana

Vol.25.3.Desember (2018): 1773 - 1798

cut off yang dipakai untuk menunjukkan adanya multikolinearitas adalah nilai VIF $\geq 10$ atau nilai tolerance $\leq 0,10$. Pada Tabel 6 disajikan Hasil uji multikolinieritas sebagai berikut.

Tabel 6.

Hasil Uji Multikolinieritas

\begin{tabular}{llccl}
\hline \multicolumn{1}{c}{ Variabel } & & Tolerance & VIF & Keterangan \\
\hline Kualitas Pelayanan & $\left(\mathrm{X}_{1}\right)$ & 0,503 & 1,989 & Bebas Multikolinieritas \\
Sanksi Pajak & $\left(\mathrm{X}_{2}\right)$ & 0,523 & 1,913 & Bebas Multikolinieritas \\
Biaya KepatuhanPajak & $\left(\mathrm{X}_{3}\right)$ & 0,475 & 2,107 & Bebas Multikolinieritas \\
Penerapan e-Filling & $\left(\mathrm{X}_{4}\right)$ & 0,384 & 2,607 & Bebas Multikolinieritas \\
\hline Sumber : Data diolah, 2018 & & & &
\end{tabular}

Sumber : Data diolah, 2018

Berdasarkan hasil perhitungan tabel diatas, nilai nilai tolerance lebih besar dari 0,1 dan nilai VIF lebih kecil dari 10, Sehingga disimpulkan bahwa antar variabel independen tidak terjadi atau bebas multikolinearitas.

Tujuan dilakukannya uji heteroskedatisitas yaitu untuk menguji apakah dalam model regresi terjadi ketidaksamaan variance dari residual untuk semua pengamatan. Uji Glejser digunakan untuk menguji uji heterokedastisitas di dalam penelitian ini. Apabila tingkat signifikansi lebih besar dari $\alpha=0,05$ maka model regresi yang dianalisis tidak adanya gejala heteroskedastisitas. Pada Tabel 7 disajikan hasil uji heteroskedastisitas, sebagai berikut.

Tabel 7.

Hasil Uji Heteroskedastisitas

\begin{tabular}{llcl}
\hline \multicolumn{1}{c}{ Variabel } & & Sig & Keterangan \\
\hline Kualitas Pelayanan & $\left(\mathrm{X}_{1}\right)$ & 0,831 & Bebas Heteroskedastisitas \\
Sanksi Pajak & $\left(\mathrm{X}_{2}\right)$ & 0,883 & Bebas Heteroskedastisitas \\
Biaya KepatuhanPajak & $\left(\mathrm{X}_{3}\right)$ & 0,625 & Bebas Heteroskedastisitas \\
Penerapan e-Filling & $\left(\mathrm{X}_{4}\right)$ & 0,656 & Bebas Heteroskedastisitas \\
\hline
\end{tabular}

Sumber: Data diolah, 2018

Hasil pengujian pada Tabel 7, tingkat signifikansi seluruh variabel berada diatas 0,05 hal ini menunjukkan model regresi dalam penelitian ini bebas dari heteroskedastisitas. 
Ida Bagus komang Wiryadana dan Ni Ketut Lely Aryani Merkusiawati. Pengaruh...

Uji Regresi Linier Berganda yang digunakan dalam penelitian ini untuk menguji pengaruh variabel kualitas pelayanan pajak, sanksi perpajakan, biaya kepatuhan pajak dan penerapan sistem $e$-filling, pada kepatuhan pelaporan WPOP non PNS. Tabel 8 menyajikan hasil dari analisis regresi linier berganda dapat dilihat sebegai berikut.

Tabel 8.

Hasil Uji Analisis Regresi Linier Berganda

\begin{tabular}{lccccc}
\hline \multirow{2}{*}{ Variabel } & \multicolumn{2}{c}{$\begin{array}{c}\text { Unstandardized } \\
\text { Coefficients }\end{array}$} & $\begin{array}{c}\text { Standardized } \\
\text { Coefficients }\end{array}$ & \multirow{2}{*}{ t } & Signifikansi \\
\cline { 2 - 4 } & $\mathbf{B}$ & Std. Error & Beta & & \\
\hline (Constant) & 3,651 & 2,230 & & 1,637 & 0,105 \\
Kualitas Pelayanan (X1) & 0,144 & 0,066 & 0,160 & 2,169 & 0,033 \\
Sanksi Pajak (X2) & 0,343 & 0,089 & 0,277 & 3,843 & 0,000 \\
Biaya Kepatuhan Pajak (X3) & $-0,147$ & 0,072 & $-0,153$ & $-2,027$ & 0,045 \\
Penerapan e-Filling (X4) & 0,402 & 0,083 & 0,409 & 4,860 & 0,000 \\
Adjusted S Square & & & 0,731 & & \\
F hitung & & & 68,187 & & \\
Signifikansi F & & & 0,00 & & \\
\hline
\end{tabular}

Sumber : Data diolah, 2018

Berdasarkan tabel diatas dapat disusun persamaan regresi adalah sebagai berikut.

$$
\mathrm{Y}=3,651+0,144 \mathrm{X}_{1}+0,343 \mathrm{X}_{2}+(-0,147) \mathrm{X}_{3}+0,402 \mathrm{X}_{4}+\mathrm{e}
$$

Tabel 8 dapat dilihat bahwa nilai dari uji $\mathrm{F}$ dalam penelitian ini yaitu 0,000 dengan signifikansi uji F $0,000<0,05$ yang berarti model regresi layak digunakan. Nilai Adjusted R Square model (Uji koefisien determinasi) pada tabel 8 sebesar 0,731 artinya 73,1 persen kepatuhan pelaporan wajib pajak orang pribadi dipengaruhi oleh kualitas pelayanan, sanksi pajak, biaya kepatuhan pajak dan penerapan sistem e-filling, sedangkan 26,9 persen dijelaskan oleh variabel lain diluar model.

Hasil pengujian variabel kualitas pelayanan pada Tabel 8 menunjukkan variabel kualitas pelayanan mempunyai koefisien regresi sebesar 0,144 dengan signifikansi sebesar 0,033 yang dimana lebih kecil dari tingkat signifikansi 0,05 
menunjukkan bahwa kualitas pelayanan berpengaruh positif dan signifikan pada kepatuhan pelaporan wajib pajak non Pegawai Negeri Sipil, sehingga $\mathrm{H}_{1}$ diterima. Hal ini mengindikasikan apabila kualitas pelayanan yang diberikan baik dan memberikan kepuasan kepada wajib pajak, maka akan cendrung meningkatkan kepatuhan pelaporan wajib pajak orang pribadi di KPP Pratama Denpasar Timur. Kepuasan yang dirasakan wajib pajak atas pelayanan yang diterima dapat meningkatkan kesadaran akan tanggungjawabnya sebagai wajib pajak untuk patuh dalam melaksanakan kewajiban perpajakannya yang pada akhirnya akan meningkatkan penerimaan negara khususnya di sektor pajak.

Hasil pengujian variabel sanksi pajak pada Tabel 8, menunjukkan variabel sanksi pajak memiliki koefisien regresi sebesar 0,343 dengan signifikansi sebesar 0,000 yang dimana lebih kecil dari tingkat signifikansi 0,05 menunjukkan bahwa sanksi pajak berpengaruh positif pada kepatuhan pelaporan wajib pajak orang pribadi non Pegawai Negeri Sipil, sehingga $\mathrm{H}_{2}$ diterima. Pandangan tentang pengenaan sanksi perpajakan yang akan lebih merugikan wajib pajak apabila melakukan penghindaran pajak menjadi faktor pendorong bagi wajib pajak untuk memenuhi kewajiban perpajakannya, sehingga salah satu cara untuk menghindari sanksi perpajakan adalah dengan memenuhi kewajiban pajak tepat pada waktunya atau tidak melewati jangka waktu yang ditetapkan. Semakin tegasnya sanksi yang diberikan, maka akan membuat WP tersebut semakin patuh.

Hasil pengujian variabel biaya kepatuhan pajak pada Tabel 8 menunjukkan Mmempunyai koefisien regresi sebesar -0,147 dengan signifikansi sebesar 0,045 yang dimana lebih kecil dari tingkat signifikansi 0,05 menunjukkan bahwa biaya 
Ida Bagus komang Wiryadana dan Ni Ketut Lely Aryani Merkusiawati. Pengaruh...

kepatuhan pajak berpengaruh negatif pada kepatuhan pelaporan wajib pajak orang pribadi non Pegawai Negeri Sipil. Jika biaya kepatuhan wajib pajak yang dikeluarkan oleh wajib pajak semakin tinggi maka tingkat kepatuhan akan semakin rendah. WP yang mematuhi kewajiban perpajakannya berharap bahwa besarnya biaya kepatuhan yang harus dikeluarkan untuk memenuhi kewajiban perpajakkannya dapat ditekan serendah mungkin. Hal ini disebabkan karena WP merasa dirugikan jika biaya kepatuhan pajak yang harus dikeluarkan sangat tinggi.

Hasil pengujian variabel Penerapan e-filling pada Tabel 8 menunjukkan koefisien regresi sebesar 0,402 dengan signifikansi sebesar 0,000 yang dimana lebih kecil dari tingkat signifikansi 0,05 menunjukkan penerapan e-filling berpengaruh positif pada kepatuhan pelaporan wajib pajak orang pribadi non Pegawai Negeri Sipil. Wajib pajak orang pribadi yang telah menggunakan sistem e-filling merasakan manfaat dalam mempermudah pelaporan pajak, sehingga wajib pajak cenderung untuk ingin melaporkan pajak yang merupakan kewajibannya. Semakin banyak wajib pajak yang sadar untuk melaporkan pajak maka semakin meningkat kepatuhan wajib pajak. Tingginya tingkat kepatuhan maka pada akhirnya akan meningkatkan pendapatan dari sektor perpajakan. Hal ini dikarenakan sistem e-filling dapat diakses dengan online dan realtime yang membuat sistem ini lebih efektif dan efisien.

Implikasi teoritis pada penelitian ini diharapkan dapat memberikan tambahan informasi mengenai bagaimana kualitas pelayanan, sanksi perpajakan, biaya kepatuhan pajak dan penerapan sistem e-filling pada kepatuhan pelaporan wajib pajak orang pribadi. Theory of Planned Behavior yang digunakan dalam 
penelitian ini dapat menjelaskan secara relevan perilaku wajib pajak dalam memenuhi kewajiban perpajakannya. Sebelum seseorang melakukan perbuatan, orang tersebut akan memiliki keyakinan akan hasil yang diperoleh dari perbuatannya tersebut. Kemudian orang itu akan memutuskan bahwa akan melakukannya atau tidak melakukannya.

Technology acceptance model (TAM), merupakan suatu model teori untuk memprediksi dan menjelaskan bagaimana pengguna teknologi menerima dan menggunakan teknologi tersebut dalam pekerjaan individual pengguna. Penelitian ini menggunakan teori TAM untuk mengetahui bagaimana penggunaan sistem $e$ filling dapat memengaruhi kepatuhan pelaporan wajib pajak orang pribadi non PNS dalam melaporkan kewajiban perpajakannya. Dengan adanya sistem $e$-filling yang dapat diakses dengan online dan realtime, diharapkan dapat memberikan kepuasan kemudahan bagi WPOP dalam melaporkan kewajiban perpajakannya sehingga dapat meningkatkan kepatuhan pelaporan pajak untuk WPOP.

Implikasi praktis dalam penelitian ini diharapkan mampu digunakan sebagai referensi, masukan dan tambahan informasi bagi wajib pajak orang pribadi bahwa kepatuhan pelaporan wajib pajak dapat membantu penerimaan negara yang nantinya dapat digunakan untuk pembangunan nasional serta meningkatkan kesejahteraan seluruh lapisan masyarakat. Penelitian ini juga diharapkan dapat menjadi sumbangan pemikiran dan bahan pertimbangan oleh pihak pembuat kebijakan perpajakan, serta menjadi pedoman bagi penelitian selanjutnya. 
Ida Bagus komang Wiryadana dan Ni Ketut Lely Aryani Merkusiawati. Pengaruh...

\section{SIMPULAN}

Berdasarkan hasil penelitian yang sudah diuraikan sebelumnya, simpulan yang dapat diperoleh adalah penelitian ini menunjukkan Kualitas pelayanan berpengaruh positif pada kepatuhan pelaporan wajib pajak orang pribadi, Hal ini menunjukkan bahwa semakin tinggi kualitas pelayanan yang diberikan oleh fiskus, maka kepatuhan pelaporan wajib pajak juga akan meningkat. Selain itu hasil penelitian menunjukkan bahwa sanksi pajak juga berpengaruh positif pada kepatuhan pelaporan pajak wajib pajak orang pribadi, Hal ini menunjukkan bahwa semakin tinggi sanksi perpajakan yang dikenakan kepada wajib pajak, maka kepatuhan pelaporan wajib pajak juga akan meningkat. Penerapan e-filling juga berpengaruh positif dan signifikan pada kepatuhan pelaporan pajak wajib pajak orang pribadi, Hal ini menunjukkan bahwa semakin tinggi penerapan e-filling yang digunakan oleh wajib pajak, maka kepatuhan pelaporan wajib pajak juga akan meningkat.

Biaya kepatuhan pajak berpengaruh negatif pada kepatuhan pelaporan wajib pajak orang pribadi non PNS di Kantor Pelayanan Pajak Pratama Denpasar Timur. Hal ini menunjukkan bahwa semakin tinggi biaya kepatuhan pajak yang dikeluarkan oleh wajib pajak, maka kepatuhan pelaporan wajib pajak pun akan semakin rendah.

Saran yang dapat peneliti usulkan dari hasil penelitian dan simpulan yang sudah dipaparkan di atas adalah Kantor Pelayanan Pajak Pratama Denpasar Timur telah memberikan pelayanan yang baik dan prima, sehingga pelayanan yang baik ini dapat dipertahankan dan ditingkatkan agar seterusnya dapat 
ISSN: 2302-8556

E-Jurnal Akuntansi Universitas Udayana

Vol.25.3.Desember (2018): 1773 - 1798

memberikan kepuasan serta kenyamanan bagi WP. Penegakkan sanksi pajak juga diharapkan dapat dilakukan sesuai dengan peraturan perundang-undangan yang berlaku dan besarnya sanksi yang diberikan harus sesuai dengan besar kecilnya pelanggaran yang dilakukan sehingga dapat meningkatkan kepatuhan wajib pajak dalam memenuhi kewajiban perpajakannya. selain itu, sosialisasi tentang penerapan sistem e-filling perlu ditingkatkan lagi pelaksanaannya, hal ini disebabkan masih ada wajib pajak orang pribadi non PNS yang belum mengetahui keberadaan dari sistem $e$-filling serta cara penggunaannya.

Bagi peneliti selanjutnya, disarankan untuk menambahkan variabel lain yang tidak digunakan dalam penelitian ini, ataupun menggunakan variabel pemoderasi dan variabel intervening untuk mengetahui tingkat kepatuhan pelaporan wajib pajak. hal tersebut masih dapat dilakukan karena nilai koefisien determinasi dalam penelitian ini masih dapat ditingkatkan dengan adanya penambahan variabel bebas.

\section{REFERENSI}

Agus, Jatmiko. 2006. Pengaruh Sikap Wajib Pajak pada Pelaksanaan Sanksi Denda, Pelayanan Fiskus, dan Kesadaran Perpajakan Terhadap Kepatuhan Wajib Pajak Studi Empiris Terhadap Wajib Pajak Orang Pribadi di Kota Semarang. Skripsi Akuntansi Unisversitas Diponegoro.

Ajzen, Icek. 1991. The Theory of Planned Behavior. Journal of Organizational Behavior and Human Decision Process, 50, 179-211.

Ali. 2001. The Effects of Tax Rates and Enforcement Polices on Tax Payer Complienace: A Study of Self Employed Tax Payers. Antlantic Economic Journal, 29 (2), 70-95.

Arum, Harjanti Puspa. 2012. Pengaruh Kesadaran Wajib Pajak, Pelayanan Fiskus, dan Sanksi Pajak terhadap Kepatuhan Wajib Pajak Orang Pribadi yang Melakukan Kegiatan Usaha dan Pekerjaan Bebas (Studi di Wilayah KPP 
Ida Bagus komang Wiryadana dan Ni Ketut Lely Aryani Merkusiawati. Pengaruh...

Pratama Cilacap). Jurnal Ekonomika dan Bisnis, Universitas Diponegoro, 1(1), 1-8.

Astuti, Inne Nidya. 2016. Analisis Penerapan E-Filling sebagai upaya Meningkatkan Kepatuhan Wajib Pajak dalam Penyampaian Surat Pemberitahuan (SPT) tahunan Pada KPP Pratama Gersik Utara. Jurnal Fakultas Ekonomi Universitas Negeri Surabaya, 3 (3), 1-25.

Burhanudin dan Rr. Iramani Subagyo. 2009. Service Quality Dimensions In Public Sector. Journal Ekonomi Bisnis dan Akuntansi Ventura, 68 (3), 7085.

Chau, Liung. 2009. A Critical Review of Fischer Tax Compliance Model (A Research Syntesis). Journal of Accounting and Taxation, 1(2), 34-40.

Cronin, J. Joseph dan Steven A. Taylor. 1992. Measuring Service Quality. Journal Of Marketing, 56, 5-10.

Davis, F.D. 1989. Perceived Usefulness, Perceived Ease of Use, and Acceptance of Information System Technologhy. MIS Quarterly. 13 (3), h.319-339.

Desmayanti, E. 2012. Faktor-Faktor yang Mempengaruhi Penggunaan Fasilitas EFiling Oleh Wajib Pajak Sebagai Sarana Penyampaian SPT Masa Secara Online dan Realtime (Kajian Empiris di Wilayah Kota Semarang). Jurnal Akuntansi, 1(1), 1-12.

Santi Krisna, Dewi. 2017. Pengaruh Kesadaran Wajib Pajak, Sanksi Perpajakan, E-Filling, dan Tax Amnesty Terhadap Kepatuhan Pelaporan Wajib Pajak. E-Journal Akuntansi Universitas Udayana, 22 (2), 1626-1655.

Farid Syahril. 2013. Pengaruh Tingkat Pemahaman Wajib Pajak dan Kualitas Pelayanan Fiskus Terhadap Tingkat Kepatuhan Wajib Pajak PPh Orang Pribadi. Jurnal Akuntansi Universitas Negeri Padang, 1 (1), 115-145.

Arabella Fuadi, Oentari dan Yenni Mangoting. 2013. Pengaruh Kualitas Pelayanan Petugas Pajak, Sanksi Perpajakan, dan Biaya Kepatuhan Pajak terhadap Kepatuhan Wajib Pajak UMKM. Tax and Accounting Review, $1(1), 18-27$.

Harahap, Abdul Asri. 2004. Pradigma Baru Perpajakan Indonesia Persefektif Ekonomi. Jakarta : Dinamika Press.

Ibtida, Reisya. 2010. Pengaruh Kesadaran Wajib Pajak dan Pelayanan Fiskus Terhadap Kinerja Penerimaan Pajak Dengan Kepatuhan Wajib Pajak 
Sebagai Variabel Intervening. E-Jurnal Ekonomi Universitas sebelas Maret Surakarta, 16, 96.

James, Simon dan Clinton Alley. 2004. Tax Compliance, Self-Assesment and Tax Adminstration. Journal of Finance and Management in Public Service, 2(2), 27:42.

Jung, Woon Oh. 1999. Taxpayer Disclousure and Penalty Laws. Seoul National University. Journal of Public Economics Theory, 2 (2), 151-742.

Keputusan Direktur Jenderal Pajak Nomor Kep-88/PJ/2004 Tentang Penyampaian Surat Pemberitahuan Secara Elektronik. (www.ortax.org)

Mardiasmo. 2016. Perpajakan. Edisi Terbaru 2016. Yogyakarta: Andi.

Max Everest-Philips. 2009. Tax Morale and State Building in Developing Countries. Journal of Development Policy Review, 28, 75-96.

Muliari, Ni Ketut. 2011. Pengaruh Persepsi tentang Sanksi Perpajakan dan Kualitas Pelayanan pada Kepatuhan Pelaporan Wajib Pajak Orang Pribadi Di Kantor Pelayanan Pajak Pratama Denpasar Timur. Jurnal Ilmiah Akuntansi dan Bisnis, 6 (1), 2303-1018.

Nugroho, Andi Setijo. 2005. Pengaruh Kualitas Pelayanan Terhadap Kepuasan Wajib Pajak. Jurnal Ekonomi Universitas Islam Indonesia, 1, 109-118.

Parmita Saha, Atanu K. Nath, Esmail Salehi-Sangari. 2012. Evaluation of Government E-Tax Websites: An Information Quality and System Quality Approach. Journal of Transforming Government: People, Process, and Policy, 6 (3), 300-321.

Peraturan Direktur Jendral Pajak Nomor PER-36/PJ/2013 mengenai Tata Cara Penyampaian Surat Pemberitahuan dan Penyampaian Pemberitahuan Perpanjangan Surat Pemberitahuan Tahunan Secara Elektronik (e-filing) melalui Application Service Provider. (www.ortax.org)

Punarbhawa, B dan Aryani M, Ni Ketut Lely. 2013. Pengaruh Reformasi Administrasi Perpajakan dan Pengetahuan Perpajakan terhadap Tingkat Kepatuhan Pengusaha Kena Pajak (PKP). E-Jurnal Akuntansi Universitas Udayana, 5 (2), 381-397.

Putri, Juniati. 2017. Pengaruh Kesadaran Wajib Pajak, Pengetahuan dan Pemahaman Peraturan Perpajakan, Kualitas Pelayanan dan Sanksi Perpajakan pada Kepatuhan Wajib Pajak Orang Pribadi di KPP Pratama Denpasar Timur. E-Jurnal Akuntansi Universitas Udayana, 18 (2), 11121140 . 
Ida Bagus komang Wiryadana dan Ni Ketut Lely Aryani Merkusiawati. Pengaruh...

Rara Susmita, Putu. 2016. Pengaruh kualitas pelayanan, sanksi perpajakan, biaya kepatuhan pajak, dan penerapan e-filing pada kepatuhan wajib pajak. $E$ Jurnal Akuntansi Universitas Udayana, 14 (2), 1239-1269.

Sandford, C. 1995. The Rise and Rise of Tax Compliance Coasts in Cedric Sandford, (Editor) Tax Compliance Cost Measurement and Policy. Journal of Bath, U.K : Fiscal Publications in Association with The Institute for Fiscal Studies. National Tax Journal, 5 (3), 229-252.

Sugiyono. 2017. Metode Penelitian (Kuantitatif, Kualitatif, dan R\&D). Bandung: Alfabeta.

Supadmi. 2009. Meningkatkan Kepatuhan Wajib Pajak Melalui Kualitas Pelayanan. E-Jurnal Akuntansi dan Bisnis Udayana, 4 (2), 2303-1018

Surat Edaran Direktur Jenderal Pajak Nomor SE-07/PJ/2017 Tentang Penetapan Target dan Pencapaian Rasio Kepatuhan Wajib Pajak. (www.pajak.go.id).

Torgler, B. 2005. Direct Democracy and Tax Morale. European Journal of Political Economy, 21(3), page: 525-531.

UU KUP No.16 Tahun 2009 Tentang Ketentuan Umum dan Tata Cara Perpajakan. (www.pajak.go.id)

Valerie Zeithaml, A. Pasuraman and Leonard Berry. 1999. A Conceptual Model of Service Quality it's Implication Future Reasearch. Journal of Marketing $7(1), 41-50$

Webley, P., H. Robben., H. Elffers dan D. Hessing. 1991. Tax Evasion: An Experimental Approach. Cambridge, United Kingdom: Cambridge University Press.

Wulandari. 2016. Pengaruh Penerapan e-Filing, Tingkat Pemahaman Perpajakan, dan Kesadaran Wajib Pajak terhadap Kepatuhan Wajib Pajak di KPP Pratama Yogyakarta. Jurnal Fakultas Ekonomi Negeri Yogyakarta, 5 (2), 117-125.

Yulitasari, Inten. 2017. Pengaruh Tanggung Jawab Moral, Sanksi Perpajakan, dan Penerapan Sistem E-Filing pada Kepatuhan Pelaporan Wajib Pajak Orang Pribadi di Kantor Pelayanan Pajak Pratama Denpasar Timur. E-Jurnal Akuntansi Universitas Udayana, 20 (2), hal.1360-1398. 